\title{
Photosynthetic performance in Eucalyptus clones cultivated in saline soil
}

\author{
Jailma Ribeiro de Andrade ${ }^{1 *}$, Sebastião de Oliveira Maia Júnior ${ }^{2}$, Andrea Francisca da Silva Santos ${ }^{1}$, \\ Vicente Mota da Silva ${ }^{3}$, Lucas Teles Bezerra', Jônatas Rodrigo Ribeiro da Silva', \\ Claudiana Moura dos Santos', Vilma Marques Ferreira', Laurício Endres'
}

${ }^{1}$ Laboratório de Fisiologia Vegetal, Centro de Ciências Agrárias, Universidade Federal de Alagoas, Campus Delza Gitaí, BR 104 Norte, Km 85, 57072-900, Rio Largo, AL, Brazil, '2Unidade Acadêmica de Engenharia Agrícola, Centro de Tecnologia e Recursos Naturais, Universidade Federal de Campina Grande, Av. Aprígio Veloso, 882, Bairro Universitário, 58429-900, Campina Grande, PB, Brazil, ${ }^{3}$ Laboratório de Ecofisiologia Aplicada à Agricultura, Faculdade de Ciências Agronômicas, Universidade Estadual Paulista Júlio de Mesquita Filho, Avenida Universitária, 3780 - CEP 18610-034, Altos do Paraíso, Botucatu, SP, Brazil

\section{A B S T R A C T}

\begin{abstract}
The aim of this study was to evaluate the photosynthetic performance of Eucalyptus clones with the aim of identifying their tolerance to soil saline stress conditions. The experiment was arranged in a randomized block design with a $3 \times 4$ factorial arrangement: in five replications, totaling 60 plots, three Eucalyptus clones were used, VC865, I224, and I144, which were exposed to four concentrations of $\mathrm{NaCl}(0$, 1,2 and $3 \mathrm{~g} \mathrm{NaCl} \mathrm{kg}^{-1}$ of soil). Clone 1144 shows mechanisms of salinity tolerance as smaller reductions in the stomatal conductance, transpiration, photosynthesis, photochemical efficiency of PSII, photosynthetic pigment content and total dry mass. On the other hand, clone 1224 presents greater physiological damage, indicating high susceptibility to salt stress, while VC865 shows moderate sensitivity to salinity. Variables related to photosynthetic performance, such as gas exchange, photochemical efficiency of PSII and photosynthetic pigments are potentially reliable physiological indicators for selecting of tolerant Eucalyptus clones to salt stress.
\end{abstract}

Keywords: Forestry species; Hybrids, Physiology; Salt stress; Tolerance

\section{INTRODUCTION}

The genus Eucalyptus has been of increasing interest in the production of fast-growing and high-yield forest feedstock (Tonello and Teixeira Filho, 2011; Silva et al., 2014). Furthermore, Eucalyptus species that are managed as short-rotation crops for bioenergy are of increasing interest in many parts of the world (Albaugh et al., 2013). For decades Eucalyptus has been planted in Brazil (Neves et al., 2013), where it occupies of 5.7 million hectares of the area of total trees planted (IBÁ, 2017).

Energy demand has been increasing with population growth and the world economy, while at the same time there is a tendency for reduction in the petroleum products supply, resulting in a greater demand for new alternative energy sources that will replace fossil fuels (Vieira et al., 2014a). Among these, biomass energy has gained a prominent position (Goldemberg, 2009). Therefore, Eucalyptus wood appears a good alternative of renewable energy, since Brazil has edaphoclimatic conditions favorable for the cultivation of this species.

The use of degraded areas considered unfit for agriculture may result in a greater number of planted forests, which could increase the industrial economy and the development of crops more resistant to abiotic stress (Lopes et al., 2015). In this context, the search for higher productivity in the forestry sector has encouraged research that identifies genetic material with greater production and greater adaptability to environmental variations (Vellini et al., 2008; Lopes et al., 2011; Harfouche et al., 2014).

Among these variations, salinized areas are increasing in all parts of the world as a consequence of irrigation practices, especially in arid and semi-arid regions. Semiarid regions are characterized by a negative hydric balance, which requires the practice of irrigation, which in turn is 
oftentimes performed with water of inferior quality. This in itself results in the excessive accumulation of salts in the soil surface, mainly $\mathrm{NaCl}$, that have harmful effects on plant growth and development (Pinheiro et al. 2008; Silva et al., 2012; Plazek et al., 2013; Brito et al., 2018).

Salinity is the main abiotic factor that limits the growth and productivity of crops worldwide (Plazek et al., 2013; Munns and Gilliham, 2015). The excess salts in the soil reduce the amount of available water for plants, leading to ion toxic effects on the metabolic processes, which in turn lead to rupture of membranes and organelles causing osmotic imbalance in the cells (Munns and Tester, 2008; Sá et al., 2015). Furthermore, besides the direct effects of salinity on plants, this causes the induction to water stress, because high concentrations of sodium increases osmotic concentration in soil, thereby inhibiting water absorption by the plant (Plazek et al., 2013).

The increase of solutes in the root zone promotes the water deficit which, consequently, causes an array of morphological, physiological and biochemical changes in plant yield (Prisco and Gomes Filho, 2010). In plants under drought stress, the stomatal closure helps reduce water loss from transpiration (Medeiros et al., 2013). Photochemical damage to photosystem II can be induced under such conditions. Consequently, there is a reduction in photosynthetic capacity and plant growth (Sengar et al., 2013; Kumar et al., 2014). Under these conditions, restriction on the entry of $\mathrm{CO}_{2}$ occurs due to the relationship between stomatal conductance, transpiration, and photosynthesis (Brito et al., 2018).

In different Eucalyptus genotypes cultivated in saline solutions presenting an electrical conductivity (EC) of $7 \mathrm{dS} \mathrm{m}^{-1}$ to $14 \mathrm{dS} \mathrm{m}^{-1}$, decrease in photosynthesis, stomatal conductance, and biomass production were found (Sixto et al. 2016), while higher salt concentrations (EC $20 \mathrm{dS} \mathrm{m}^{-1}$ to $40 \mathrm{dS} \mathrm{m}^{-1}$ ) were lethal to the plants (Bhargava et al., 2014). Other studies involving different species such as Ricinus communis L. (Pinheiro et al., 2008) and Jatropha curcas L. (Cavalcante et al., 2018) also found reductions due to salinity of stomatal conductance, photosynthesis, photosynthetic pigments, maximum photochemical efficiency of photosystem II, and total dry matter.

Thus, a simple way to reduce the problem of soil salinity is to study the physiological behavior of the plants that are exposed to such conditions, in order to identify salt-tolerant genotypes (Munns, 2005; Ahmed et al., 2015). The most commonly used method to set the sensitivity to salinity of tree species is saline irrigation water (Campos et al., 2012; Hishida et al., 2014). However, studies on the physiological responses of Eucalyptus to soil salinity are still scarce.
Therefore, our goal was to evaluate the photosynthetic performance of Eucalyptus clones in order to identify their tolerance to soil saline stress conditions.

\section{MATERIAL AND METHODS}

\section{Study area and experimental design}

The experiment was conducted in a greenhouse in the Laboratory of Plant Physiology at the Federal University of Alagoas, located in the municipality of Rio Largo-AL $\left(09^{\circ} 28\right.$ ' $\mathrm{S}, 35^{\circ} 49^{\prime} \mathrm{W}$, at an altitude of $127 \mathrm{~m}$ ).

Three Eucalyptus clones were chosen due to their importance in the Alagoas State plantations. Thus, clones VC865, I224, and I144 were selected, which resulted from the hybridization process between E. grandis and E. urophylla, classified as tolerant, tolerant and moderately tolerant to drought, respectively (Muller et al., 2017).

The clones were cultivated in plastic pots containing $20 \mathrm{~kg}$ of sandy loam soil, which was salinized with $\mathrm{NaCl}$ addition on a dry weight basis at four different salt concentrations: 0 (control), 1, 2 and $3 \mathrm{~g} \mathrm{NaCl} \mathrm{kg}^{-1}$ of soil. The material remained incubated and was maintained at field capacity for four months, increasing the electrical conductivity (EC) of the soil of 2 ( $0 \mathrm{~g}$ of $\mathrm{NaCl} \mathrm{kg}-1$ of soil-control) for 6,10 and $12 \mathrm{dS} \mathrm{m}^{-1}$ at the concentrations of 1,2 and $3 \mathrm{~g}$ of $\mathrm{NaCl}$ $\mathrm{kg}^{-1}$ of soil, respectively. The EC of the soil was estimated according to Richards (1954).

The Eucalyptus seedlings were acquired in a commercial nursery, were produced in tubes by the cutting method, and were age of 120 days and homogeneous sizes. The seedlings were then transplanted into plastic bags with a soil capacity of $750 \mathrm{~g}$, and stayed in the bags for 30 days, at which time they were transplanted into pots containing $20 \mathrm{~kg}$ of salinized soil. The soil was fertilized following the recommendation of Novais et al. (1991), for basic soil fertilization. Each pot was irrigated with distilled water on a daily basis during the entire plant growth period to keep rates close to field capacity. During this period, the drained water was collected and replaced by collectors present in the pot to maintain the EC of the soil.

The experiment design was randomized block design with factorial arrangement $3 \times 4$ ( 3 clones and 4 saline concentrations in the soil), with five replications totaling 60 plots, consisting of one plant per pot.

Environmental conditions were monitored during the experiment at an automatic weather station (model WSGP1; DELTA-T Devices, Cambridge, England) located inside the greenhouse. Temperature and relative air humidity mean were recorded every $5 \mathrm{~min}$; solar radiation was measured 
every 10 s. Vapor pressure deficit (VPD) was calculated based on temperature and relative humidity (Fig. 1).

\section{Physiological analysis}

The evaluations were made at 30 and 60 days after transplanting (DAT). Gas exchange, maximum photochemical efficiency of PSII $(\mathrm{Fv} / \mathrm{Fm})$, and relative index of chlorophyll (SPAD) were performed on completely expanded leaves of the middle third of the plants, after which, at $60 \mathrm{DAT}$, photosynthetic pigments were measured from leaves collected from the same plants in which the gas exchange was evaluated.

Gas exchange measurements were performed with a gas analyzer model Li-6400XT (Infra Red Gas Analyzer - IRGA, Licor, USA) in the period between 8 am and $10 \mathrm{am}$. The variables stomatal conductance $(g \mathrm{~s})$, transpiration $(E)$, internal $\mathrm{CO}_{2}$ concentration $(C i)$, liquid photosynthesis $(A)$ and leaf temperature (LT) were obtained. The vapor pressure deficit between the leaf and the air, VPD (leaf-air) and instantaneous carboxylation efficiency $(A / \mathrm{Ci})$ correlated liquid photosynthesis with the internal $\mathrm{CO}_{2}$ concentration.

The measurements of the maximum quantum efficiency of PSII $(\mathrm{Fv} / \mathrm{Fm})$ were made at predawn $(4: 30 \mathrm{am})$ and at midday (12:00 pm) using a portable modulated light fluorometer (PAM 2500, WALZ), according to method described by Maxwell and Johnson (2000). Completely expanded leaves of the middle third of the plants were adapted to the dark for $30 \mathrm{~min}$ with the aid of special leaf clips placed in the intermediate part of the leaf.

The estimated chlorophyll content, the SPAD index, was performed by a portable device model SPAD-502 (Minolta, Japan), and averages obtained from five readings were measured on fully expanded leaves of the middle third of the plant.
The analysis of chlorophylls $a, b$, total and carotenoids was made according to the method described by Lichtenthaler (1987), where the extract was obtained using five leaf disks with $0.6 \mathrm{~cm}^{2}$ that were immersed in threaded test tubes protected from light with aluminum foil and containing $5 \mathrm{~mL}$ of $80 \%$ acetone for $72 \mathrm{~h}$ with regular shaking. The reading of absorbance was subsequently taken by a spectrophotometer at wavelengths of 480, 645 and $663 \mathrm{~nm}$.

At the end of the experiment, plants were collected after drying in a forced air circulation oven for $72 \mathrm{~h}$ at $65^{\circ} \mathrm{C}$ until constant weight, obtaining the total dry mass (TDM).

\section{Statistical analysis}

The experimental data were submitted to the analysis of variance ( $F$ test), the soil salinity factor being analyzed by means of polynomial regression and the clone factor being analyzed by the Tukey test, with $\mathrm{P}<0.05$. Pearson's (r) correlation was used to verify the relationship between the physiological variables analyzed within each saline condition.

\section{RESULTS}

\section{Physiological analysis}

Gas exchange variables were affected by soil salinity in the Eucalyptus clones, both at 30 and 60 days after transplanting (DAT). The foliar temperature (LT) at $30 \mathrm{DAT}$ increased in all clones studied with the increase of soil salinity (Fig. 2A). In clones VC865, I224 and I144 increased leaf temperature at very high salt concentrations $\left(3 \mathrm{~g} \mathrm{NaCl} \mathrm{kg}^{-1}\right.$ of soil), when compared with control, in order of $3.32 \%, 3.97 \%$ and $2.84 \%$, respectively (Fig. 2A). It was observed at $60 \mathrm{DAT}$ that clone VC865 maintained the leaf temperature constant, while concentrations of I224 and I144 increased by $2.63 \%$ and $2.59 \%$, respectively, for the highest concentration of $\mathrm{NaCl}$ in the soil (Fig. 2B).

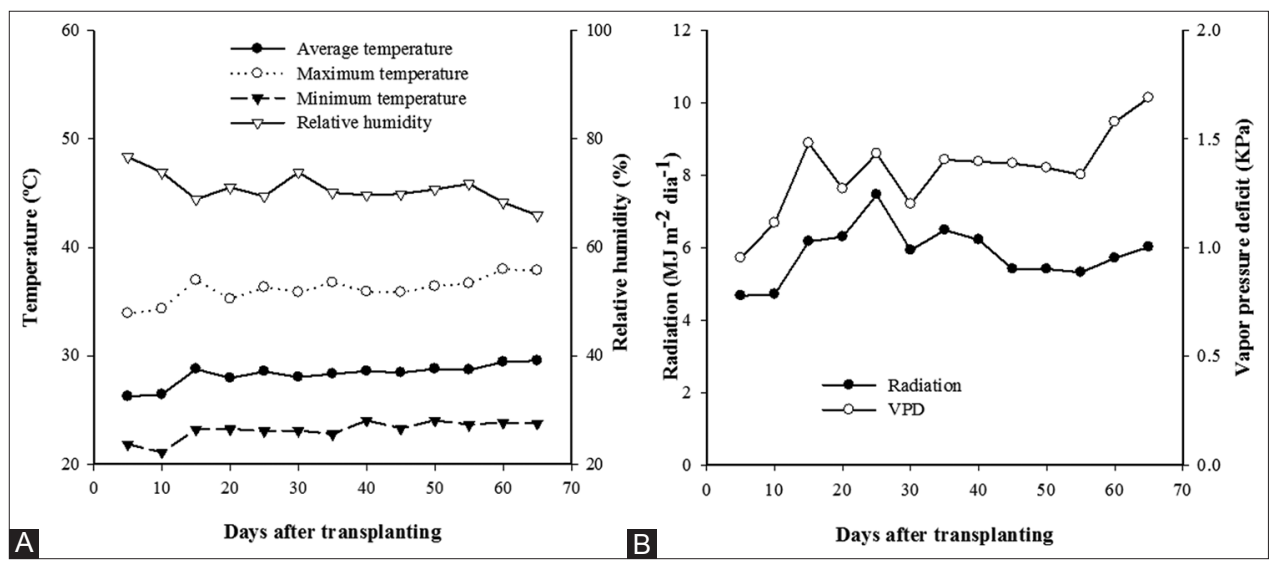

Fig 1. Maximum, minimum and average air temperatures and mean relative humidity $(A)$, mean incident radiation and vapor pressure deficit (B) inside the greenhouse during the period of salt stress. 
Similar behavior was observed for leaf-to-air vapor pressure deficit (VPD leaf-air), where at 30 DAT the clones VC865, I224 and I144 showed increases of $21.56 \%, 16.70 \%$ and $27.69 \%$, respectively, when they were compared with control plants for the highest salinity level of $3 \mathrm{~g} \mathrm{NaCl} \mathrm{kg}^{-1}$ of soil (Fig. 2C). Already at $60 \mathrm{DAT}$, clones VC865, I224, and I144 presented more moderate increases of DPV (leaf-air) of 7.05\%, 7.50\% and $14.06 \%$, respectively, in function of the salinity (Fig. 2D). At 60 DAT, the DPV (leaf-air) showed an inverse correlation with the transpiration in all saline conditions studied (Table 1). Besides that, in the same period, the VPD (leaf-air) presented an inverse correlation with $g s$ in the plants traded with the saline concentrations of 1 and $3 \mathrm{~g}$ $\mathrm{NaCl} \mathrm{kg}{ }^{-1}$ of soil.

The clones presented reduction of stomatal conductance and transpiration with the increase of salt concentration in the soil in both evaluated periods. At 30 DAT, clones VC865, I224, and I144 observed reductions of gs of $30.33 \%, 42.76 \%$, and $46.59 \%$, respectively, with increasing soil salinity up to concentration of $3 \mathrm{~g}$ $\mathrm{NaCl} \mathrm{kg}{ }^{-1}$ of soil (Fig. 3A). Already at $60 \mathrm{DAT}$, clone I144 increased the stomatal conductance up to the value of $1.67 \mathrm{~g} \mathrm{NaCl} \mathrm{kg}^{-1}$ of soil, presenting a lower stomatal closure at the concentration of $3 \mathrm{~g} \mathrm{NaCl} \mathrm{kg}^{-1}$ of soil when compared with the other clones. By contrast, clones VC865 and I224 showed decreases of gs of $38.26 \%$ and $40.52 \%$, respectively, at the highest level of soil salinity (Fig. 3B).
Regarding transpiration, it was observed that at 30 DAT, the clones VC865, I224 and I144 presented decreases of $20.51 \%, 33.39 \%$ and $49.68 \%$, respectively, as the concentration of $\mathrm{NaCl}$ in the soil was increased (Fig. 3C). At 60 DAT, there was increase of $E$ in clone I144 with increase of salinity up to $1.67 \mathrm{~g} \mathrm{NaCl} \mathrm{kg}^{-1}$ of soil, decreasing from this concentration, similarly to $g s$. On the other hand, clones VC865 and I224 showed no changes in this evaluation period in $E$ with the increase of soil salinity (Fig. 3D). Between zero concentration and $2 \mathrm{~g} \mathrm{NaCl} \mathrm{kg}^{-1}$ of soil, a positive correlation of $g s$ and $E$ (Table 1) was found.

With the increase of soil salinity, the internal $\mathrm{CO}_{2}$ concentration at 30 DAT increased at $8.08 \%$ and $09.65 \%$, respectively, in clones VC865 and I144, with the increase of soil salinity, while clone I224 was not affected by salinity (Fig. 4A). Already at 60 DAT, clones VC865, I224, and I144 under maximum salt stress showed a more significant increase of $\mathrm{C} i$ of the order of $16.62 \%, 19.77 \%$ and $12.96 \%$, respectively (Fig. 4B).

Similar to $g s$ and $E$, the photosynthetic rate of clones decreased with increasing soil salinity. Clones VC865, I224 and I144 at 30 DAT presented reductions of $16.58 \%$, $22.76 \%$ and $33.36 \%$, respectively (Fig. 4C). Already at 60 DAT, clone I144 showed an increase in the photosynthetic rates in the concentrations of moderate salt stress (up to $0.96 \mathrm{~g} \mathrm{NaCl} \mathrm{kg}^{-1}$ of soil), but higher levels of salt concentration caused their decrease. On the other hand,

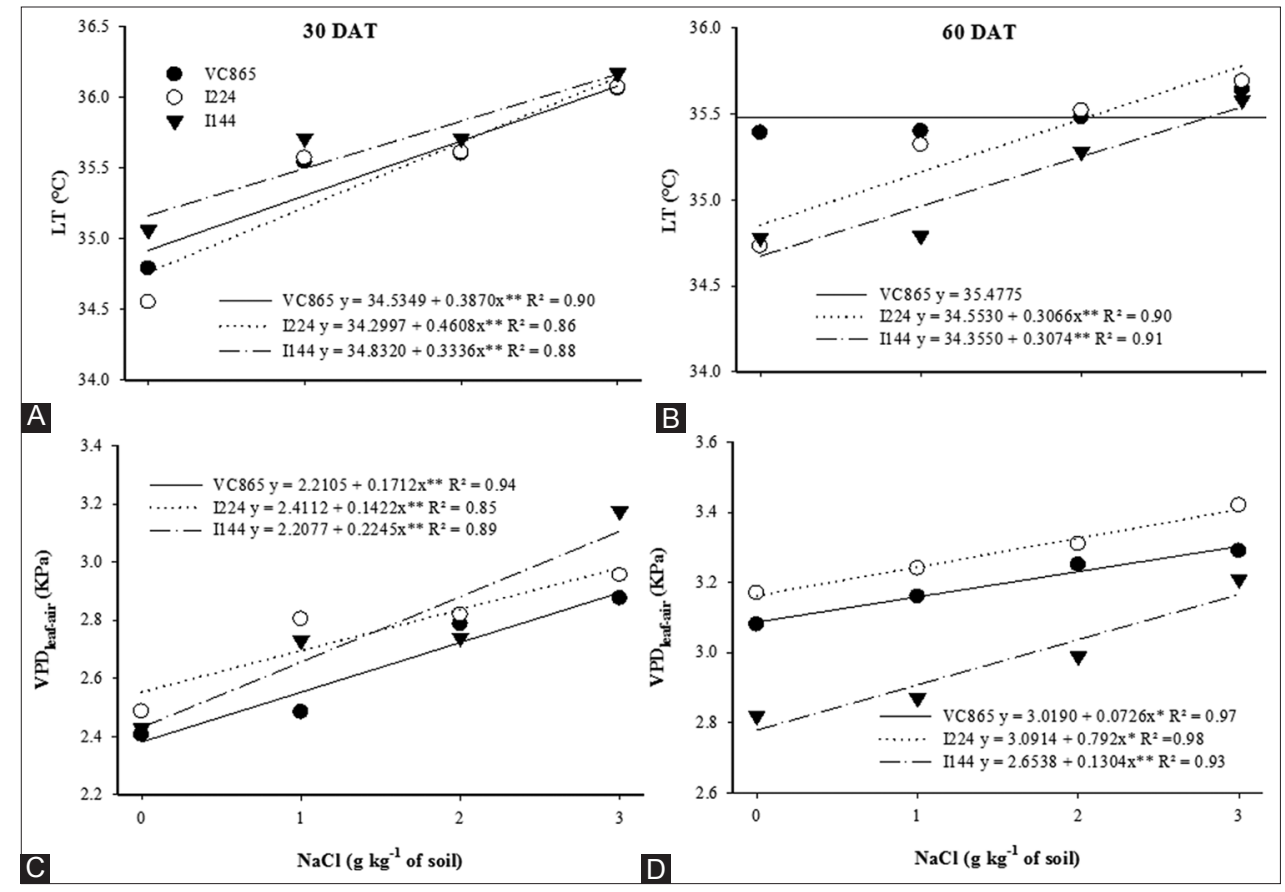

Fig 2. Leaf temperature - LT (A and B) and leaf-to-air vapor pressure deficit - VPD (air-leaf) (C and D) at 30 and 60 days after transplanting in Eucalyptus clones grown at different soil salinity levels. 
Andrade, et al.

Table 1: Pearson correlation between physiological characteristics at 60 days after transplanting in Eucalyptus clones cultivated at different soil salinity levels

\begin{tabular}{|c|c|c|c|c|c|c|c|c|c|c|c|c|c|}
\hline$S$ & Var & VPD & gs & $E$ & $\mathrm{Ci}$ & $A$ & $\mathrm{~A} / \mathrm{Ci}$ & Fv/Fm & $\mathrm{Chl}$ a & Chl b & Chl T & Car & TDM \\
\hline \multirow[t]{12}{*}{0} & LT & 0,12 & $-0,26$ & $-0,08$ & 0,10 & 0,24 & 0,24 & $-0,51$ & $-0,26$ & $-0,07$ & $-0,24$ & $-0,32$ & $-0,69^{*}$ \\
\hline & VPD & & $-0,69^{*}$ & $-0,90^{*}$ & $-0,19$ & $-0,62^{*}$ & $-0,61^{*}$ & 0,20 & $-0,21$ & 0,41 & 0,08 & $-0,63^{*}$ & $-0,28$ \\
\hline & gs & & & $0,75^{\star}$ & $-0,06$ & $0,75^{\star}$ & $0,78^{*}$ & $-0,20$ & 0,15 & $-0,50$ & $-0,18$ & $0,57^{*}$ & 0,49 \\
\hline & $E$ & & & & 0,04 & $0,69^{*}$ & $0,72^{*}$ & $-0,24$ & 0,11 & $-0,29$ & $-0,09$ & 0,46 & 0,30 \\
\hline & $\mathrm{Ci}$ & & & & & 0,33 & 0,20 & $-0,11$ & 0,03 & 0,21 & 0,15 & 0,00 & $-0,39$ \\
\hline & $A$ & & & & & & $0,98^{*}$ & $-0,35$ & 0,03 & $-0,26$ & $-0,12$ & 0,41 & $-0,09$ \\
\hline & $\mathrm{A} / \mathrm{Ci}$ & & & & & & & $-0,33$ & 0,02 & $-0,28$ & $-0,15$ & 0,41 & $-0,06$ \\
\hline & $\mathrm{Fv} / \mathrm{Fm}$ & & & & & & & & 0,23 & 0,48 & 0,46 & $-0,01$ & 0,05 \\
\hline & Chl a & & & & & & & & & 0,10 & $0,80^{*}$ & $0,55^{\star}$ & 0,15 \\
\hline & Chl $b$ & & & & & & & & & & $0,67^{*}$ & $-0,41$ & $-0,40$ \\
\hline & $\mathrm{Chl} \mathrm{T}$ & & & & & & & & & & & 0,16 & $-0,12$ \\
\hline & Car & & & & & & & & & & & & 0,23 \\
\hline \multirow[t]{12}{*}{1} & LT & $0,68^{*}$ & $-0,75^{\star}$ & $-0,73^{*}$ & $-0,58^{*}$ & $-0,70^{*}$ & $-0,65^{*}$ & $-0,44$ & $-0,42$ & 0,15 & $-0,28$ & $-0,39$ & $-0,50$ \\
\hline & VPD & & $-0,86^{*}$ & $-0,68^{*}$ & $-0,61^{*}$ & $-0,70^{*}$ & $-0,67^{*}$ & $-0,51^{*}$ & 0,05 & $0,53^{*}$ & 0,21 & $-0,21$ & $-0,19$ \\
\hline & gs & & & $0,86^{*}$ & $0,62^{*}$ & $0,84^{*}$ & $0,82^{*}$ & $0,61^{*}$ & 0,04 & $-0,38$ & $-0,08$ & 0,47 & 0,43 \\
\hline & $E$ & & & & $0,62^{*}$ & $0,98^{*}$ & $0,97^{*}$ & $0,63^{*}$ & 0,12 & $-0,05$ & 0,08 & $0,57^{\star}$ & 0,43 \\
\hline & $\mathrm{Ci}$ & & & & & $0,66^{*}$ & $0,54^{*}$ & $0,76^{\star}$ & 0,03 & $-0,25$ & $-0,05$ & 0,23 & 0,24 \\
\hline & $A$ & & & & & & $0,98^{*}$ & $0,63^{*}$ & 0,00 & $-0,12$ & $-0,03$ & 0,45 & 0,31 \\
\hline & $\mathrm{A} / \mathrm{Ci}$ & & & & & & & $0,56^{*}$ & $-0,00$ & $-0,08$ & $-0,03$ & 0,46 & 0,29 \\
\hline & $\mathrm{Fv} / \mathrm{Fm}$ & & & & & & & & 0,23 & 0,01 & 0,19 & $0,57^{\star}$ & 0,48 \\
\hline & $\mathrm{Chl} \mathrm{a}$ & & & & & & & & & $0,57^{*}$ & $0,96^{*}$ & $0,52^{*}$ & $0,60^{*}$ \\
\hline & Chl $b$ & & & & & & & & & & $0,76^{*}$ & 0,27 & 0,21 \\
\hline & $\mathrm{Chl} \mathrm{T}$ & & & & & & & & & & & 0,49 & $0,54^{*}$ \\
\hline & Car & & & & & & & & & & & & $0,89^{*}$ \\
\hline \multirow[t]{12}{*}{2} & LT & 0,45 & $-0,36$ & $-0,38$ & 0,18 & $-0,42$ & $-0,42$ & $-0,10$ & $-0,29$ & $-0,31$ & $-0,31$ & $-0,46$ & $-0,68^{*}$ \\
\hline & VPD & & $-0,50$ & $-0,77^{*}$ & 0,37 & $-0,54^{*}$ & $-0,54^{*}$ & $-0,55^{\star}$ & $-0,52^{*}$ & $-0,39$ & $-0,51$ & $-0,62^{*}$ & $-0,66^{*}$ \\
\hline & gs & & & $0,67^{\star}$ & $-0,10$ & $0,65^{*}$ & $0,62^{*}$ & $0,58^{*}$ & 0,20 & 0,26 & 0,22 & $0,78^{*}$ & $0,60^{*}$ \\
\hline & $E$ & & & & $-0,29$ & $0,76^{*}$ & $0,74^{*}$ & $0,64^{*}$ & 0,21 & 0,21 & 0,22 & $0,72^{*}$ & $0,52^{*}$ \\
\hline & $\mathrm{Ci}$ & & & & & $-0,44$ & $-0,55^{\star}$ & $-0,30$ & $-0,33$ & $-0,25$ & $-0,32$ & $-0,31$ & $-0,36$ \\
\hline & $A$ & & & & & & $0,99^{*}$ & $0,66^{*}$ & 0,35 & 0,38 & 0,38 & $0,74^{*}$ & $0,62^{*}$ \\
\hline & $\mathrm{A} / \mathrm{Ci}$ & & & & & & & $0,65^{*}$ & 0,37 & 0,39 & 0,40 & $0,74^{*}$ & $0,62^{*}$ \\
\hline & $\mathrm{Fv} / \mathrm{Fm}$ & & & & & & & & 0,09 & 0,21 & 0,13 & $0,74^{*}$ & $0,53^{*}$ \\
\hline & Chl a & & & & & & & & & $0,78^{*}$ & $0,98^{*}$ & 0,30 & $0,62^{*}$ \\
\hline & Chl $b$ & & & & & & & & & & $0,88^{*}$ & 0,34 & $0,61^{*}$ \\
\hline & $\mathrm{Chl} \mathrm{T}$ & & & & & & & & & & & 0,33 & $0,65^{*}$ \\
\hline & Car & & & & & & & & & & & & $0,83^{*}$ \\
\hline \multirow[t]{12}{*}{3} & $\mathrm{LT}$ & 0,44 & $-0,23$ & $-0,21$ & $-0,05$ & $-0,13$ & $-0,12$ & 0,02 & $-0,34$ & 0,20 & $-0,17$ & $-0,08$ & $-0,06$ \\
\hline & VPD & & $-0,69^{*}$ & $-0,53^{*}$ & 0,04 & $-0,59^{*}$ & $-0,57^{*}$ & $-0,27$ & $-0,48$ & $-0,12$ & $-0,41$ & $-0,27$ & $-0,56^{\star}$ \\
\hline & gs & & & 0,42 & $-0,29$ & $0,79^{*}$ & $0,78^{*}$ & $0,53^{*}$ & 0,43 & 0,32 & 0,45 & $0,57^{*}$ & $0,77^{*}$ \\
\hline & $E$ & & & & 0,02 & 0,38 & 0,35 & 0,10 & 0,06 & $-0,20$ & $-0,03$ & 0,13 & 0,46 \\
\hline & $\mathrm{Ci}$ & & & & & $-0,45$ & $-0,52^{*}$ & $-0,35$ & 0,14 & $-0,29$ & $-0,01$ & $-0,35$ & $-0,39$ \\
\hline & $A$ & & & & & & $0,99^{*}$ & $0,62^{*}$ & 0,43 & 0,35 & 0,46 & $0,64^{*}$ & $0,89^{*}$ \\
\hline & $\mathrm{A} / \mathrm{Ci}$ & & & & & & & $0,63^{*}$ & 0,41 & 0,36 & 0,45 & $0,65^{*}$ & $0,89^{*}$ \\
\hline & $\mathrm{Fv} / \mathrm{Fm}$ & & & & & & & & $0,57^{*}$ & $0,68^{*}$ & $0,70^{*}$ & $0,78^{*}$ & $0,76^{*}$ \\
\hline & Chl a & & & & & & & & & 0,45 & $0,93^{*}$ & $0,67^{\star}$ & $0,58^{*}$ \\
\hline & Chl $b$ & & & & & & & & & & $0,75^{\star}$ & 0,49 & 0,42 \\
\hline & Chl T & & & & & & & & & & & $0,70^{*}$ & $0,60^{*}$ \\
\hline & Car & & & & & & & & & & & & $0,83^{*}$ \\
\hline
\end{tabular}

S: soil salinity; Var: variables; LT: leaf temperature; VPD ${ }_{\text {(air-leaf) }}$ Leaf-air vapor pressure deficit; gs: stomatal conductance, E: perspiration; $\mathrm{Ci}$ internal $\mathrm{CO}_{2}$ concentration; A: photosynthesis; EiC: carboxylation efficiency; Fv/Fm: Maximum PSII efficiency at noon; Chl a: chlorophyll a; Chl b: Chlorophyll b; Chl t: total chlorophyll; Car: carotenoids; TDM: total dry mass. *significant at $\mathrm{P}<0.05$.

$A$ was progressively reduced by salinity in clones VC865 and I224 at $23.47 \%$ and $32.10 \%$, respectively (Fig. 4D). With increase of the salinity of the soil until concentration
$2 \mathrm{~g} \mathrm{NaCl} \mathrm{kg}^{-1}$ of soil, there was a positive correlation of $A$ with $g s$ and $E$, but no correlation was observed at the highest salinity level (Table 1). 


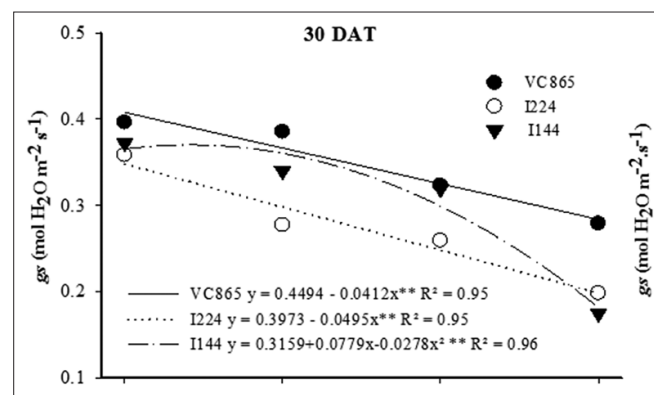

A

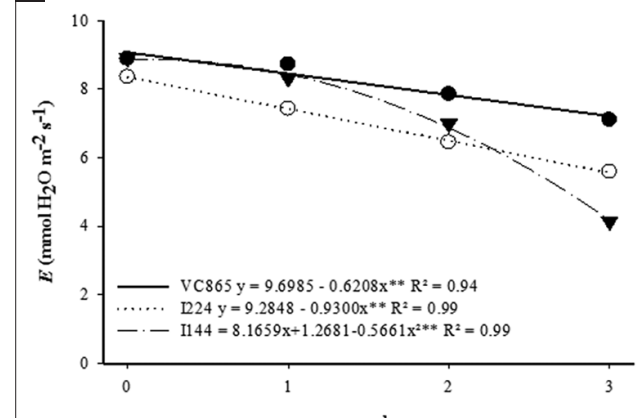

C

$\mathrm{NaCl}\left(\mathrm{g} \mathrm{kg}^{-1}\right.$ of soil)

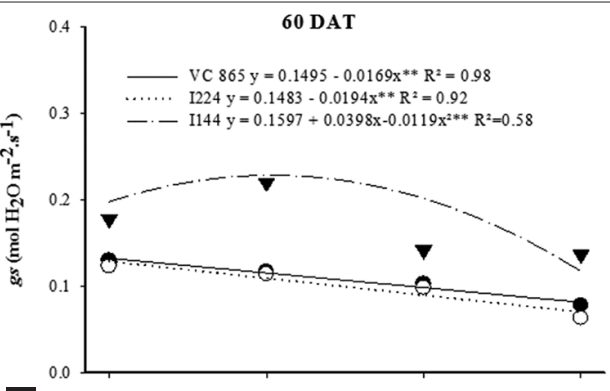

B

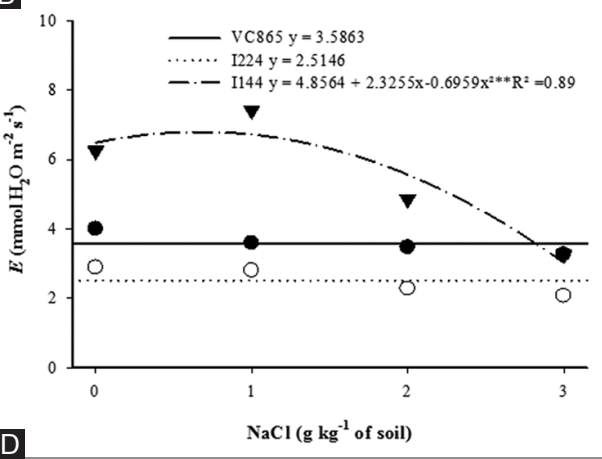

Fig 3. Stomatal conductance - gs (A and $\mathrm{B})$ and transpiration - $E(\mathrm{C}$ and $\mathrm{D})$ at 30 and 60 days after transplanting in Eucalyptus clones grown at differentsoil salinity levels.
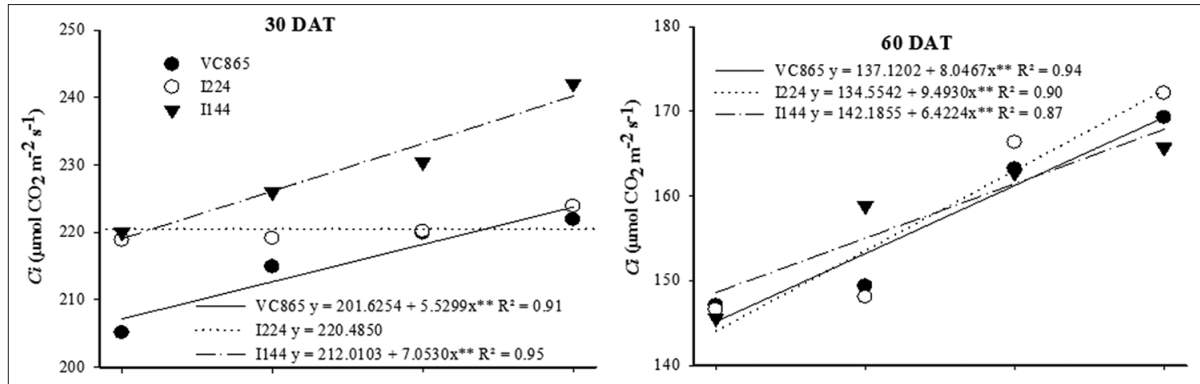

A
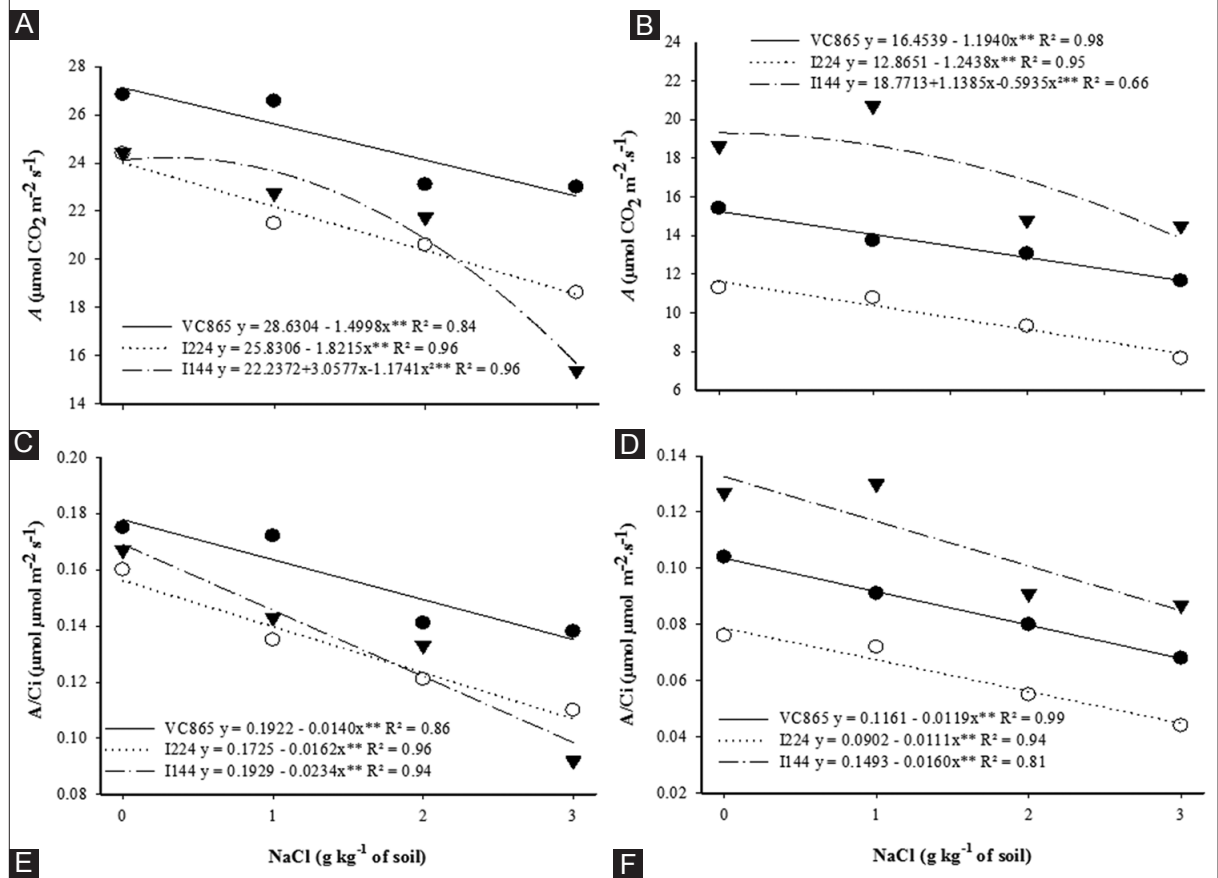

Fig 4. Internal $\mathrm{CO}_{2}$ concentration - $\mathrm{Ci}(\mathrm{A}$ and $\mathrm{B})$, photosynthesis - $A(\mathrm{C}$ and $\mathrm{D})$ and Efficiency of carboxylation - $A / \mathrm{Ci}(\mathrm{E}$ and $\mathrm{F})$ at 30 and 60 days after transplanting in Eucalyptus clones grown at different salinity levels. 
The carboxylation efficiency (A/Ci) was reduced in all clones with increasing soil salinity, in both studied periods. Clones VC865, I224 and I144 at 30 DAT showed decreases of $A / \mathrm{Ci}$ of $23.68 \%, 31.15 \%$ and $41.41 \%$, respectively (Fig. 4E), while at 60 DAT, clones VC865, I224 and I144 showed decreases of $34.35 \%, 42.35 \%$, and $33.15 \%$, respectively (Fig. 4F). $A / \mathrm{Ci}$ showed a strong positive correlation with $A$ at all levels of soil salinity (Table 1).

The maximum quantum efficiency of PSII ( Fv/Fm) in the Eucalyptus clones at predawn reduced as the soil salinity increased, both at 30 and 60 DAT, being the case that, in the first evaluation period, clones VC865, I224 and I144 showed decreases of $1.13 \%, 1.12 \%$ and $0.87 \%$, respectively, from the lowest to the highest level of soil salinity (Fig. 5A), while at $60 \mathrm{DAT}$, these decreases in clones VC865, I224 and I144 were 0.98\%, 1.92\% and $0.77 \%$, respectively (Fig. 5B).
At midday, the decreases of $\mathrm{Fv} / \mathrm{Fm}$ in the Eucalyptus clones that were caused by salinity, were slightly larger. Clones VC865, I224, and I144 at 30 DAT showed a reduction of the order of $3.49 \%, 4.38 \%$ and $2.86 \%$, respectively (Fig. 5C). Already at 60 DAT, the decreases were $2.58 \%$, $4.27 \%$ and $2.14 \%$ for the respective clones (Fig. 5D).

It can also be verified that clone I144 presented higher values at the $60 \mathrm{DAT}$ in the Fv/Fm ratio, of 0.826 at 4:30 am and 0.788 at 12:00 pm, when compared with the other clones in the higher salt concentration level. The Fv/Fm showed a positive correlation with $\mathrm{Chl} a, \mathrm{Chl} b, \mathrm{Chl} \mathrm{T}$ and Car in plants at $3 \mathrm{~g} \mathrm{NaCl} \mathrm{kg}^{-1}$ of soil (Table 1).

The estimated chlorophyll content (SPAD index) in clones VC865, I224 and I144 at 30 DAT reduced with increasing saline concentration in the soil. If there are decreases of $12.12 \%, 14.04 \%$ and $7.79 \%$, respectively, comparing the

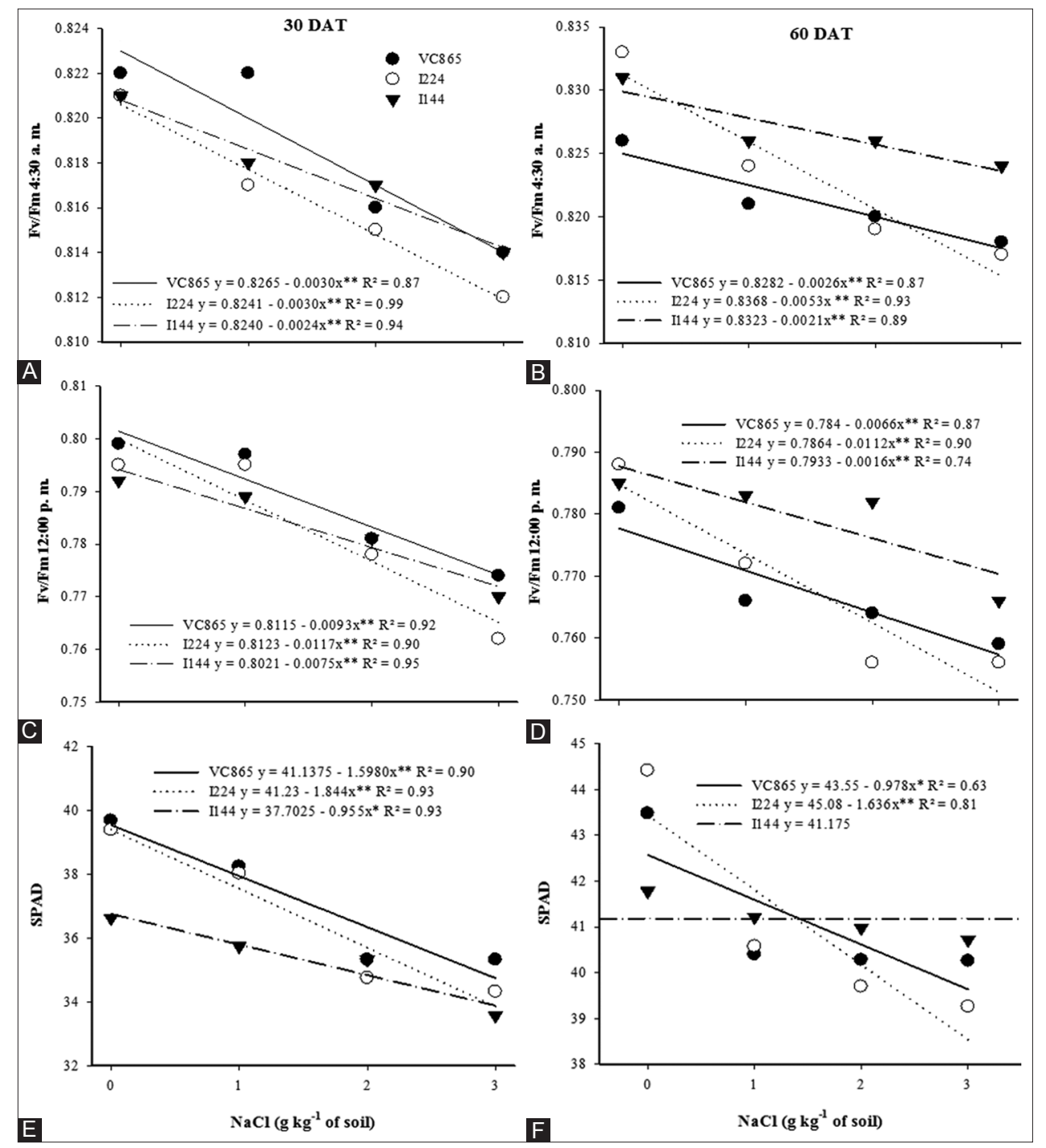

Fig 5. Maximum photochemical efficiency of PSII - Fv/Fm, at predawn (A and B) and midday (C and D) and Chlorophyll estimated content (SPAD index) ( $\mathrm{E}$ and $\mathrm{F}$ ) at 30 and 60 days after transplanting in clones of Eucalyptus cultivated at different soil salinity levels. 
lowest with the highest salinity (Fig. 5E). At 60 DAT, the salinity caused decreases of SPAD in VC865 and I224 of $6.89 \%$ and $11.29 \%$, respectively, while I144 was not affected (Fig. 5F).

Photosynthetic pigments, determined only at 60 DAT, were affected by soil salinity, which varied among the clones. Chlorophyll a reduced $33.74 \%$ in I224, from the lowest to the highest level of soil salinity, while the remaining clones were not affected (Fig. 6A). The chlorophyll content $b$ in clones VC865 and I224 decreased to $25.85 \%$ and $43.80 \%$, respectively, from the lowest to the highest salinity level, while it remained stable at clone I144 (Fig. 6B), which also presented little variation with increased salinity in the contents of $\mathrm{Chl} \mathrm{T}$. However, there were reductions in clones VC865 and I224 of $19.56 \%$ and $36.50 \%$, respectively (Fig. 6C).

The carotenoids reduced with the increase of the salinity in VC865, I224 and I144, in the order of $17.19 \%, 28.74 \%$ and $12.58 \%$, respectively (Fig. 6D). Besides that, it may be noted that clone I144 presented higher levels of Chl $\mathrm{T}$ and carotenoids when compared with the other clones in the highest concentration of salinity in the soil. There was high correlation between chlorophylls $a$ and $b$ with Chl T on all saline levels (Table 1). In the same way, positive correlation between $\mathrm{Chl} \mathrm{T}$ and carotenoids in the concentration of $3 \mathrm{~g}$ $\mathrm{NaCl} \mathrm{kg}{ }^{-1}$ of soil can be observed.

Total dry mass (TDM) was also affected by increased soil salinity in all clones (Fig. 7). Reductions were observed in
VC865, I224 and I144 of 70.71\%, 75.38\% and $69.68 \%$, respectively. This variable presented an inverse correlation with the VPD (leaf-air), as well as positive correlation with $g s, A, \mathrm{EiC}, \mathrm{Fv} / \mathrm{Fm}, \mathrm{Chl} a, \mathrm{Chl} \mathrm{T}$ and carotenoids in the two largest saline concentrations in the soil.

\section{DISCUSSION}

In this study, we verified increases of VPD (leaf-air) and foliar temperature with the increase from soil salinity, in particular in clone I224. The lowest rates of VPD (leaf-air) and LT were observed in clone I144, indicating possible acclimatization of these plants to saline stress. According to Vieira et al. (2014b), leaf temperature reduces the extent to which transpiration increases in the function of energy dissipation in the form of latent heat, contributing to leaf cooling.

Besides that, the Eucalyptus clones submitted to salt stress showed an inverse correlation between VPD (leaf-air) with stomatal conductance and transpiration. In that the increase of the VPD (leaf-air) possibly influenced in the stomatal closure and the reduction of the transpiration probably due to the low water availability present in the saline soil (Pinheiro et al., 2008; Santos et al., 2017).

In the most C3 species, high values of VPD (leaf-air) are related to stomatal closure as well as high values of VPD (leaf-air) reducing transpiration, especially when developed in environments with low soil water availability (Santos et al., 2017).

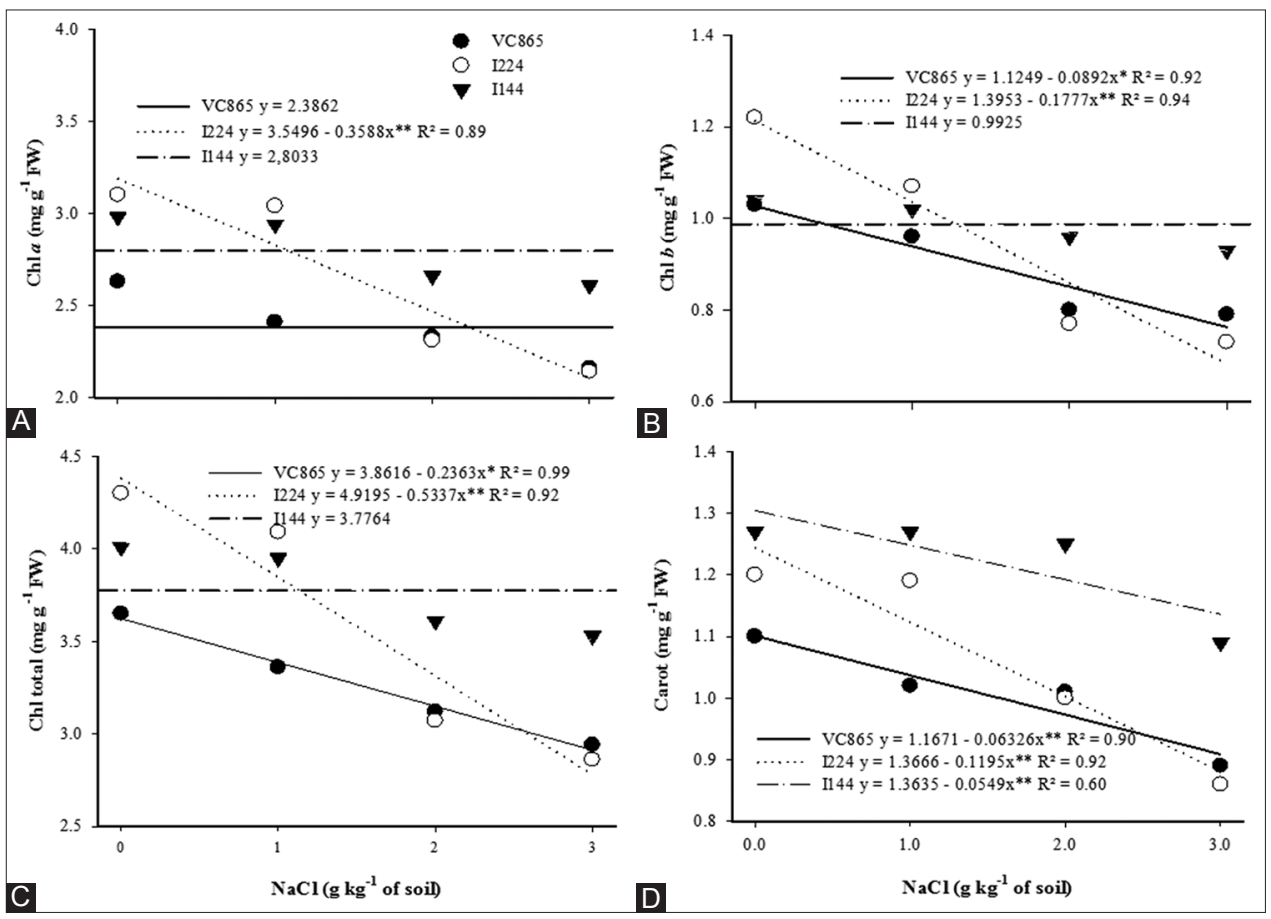

Fig 6. Chlorophyll a (A), b (B), total (C) and carotenoids (D) at 60 days after transplanting in Eucalyptus clones grown at different soil salinity levels. 


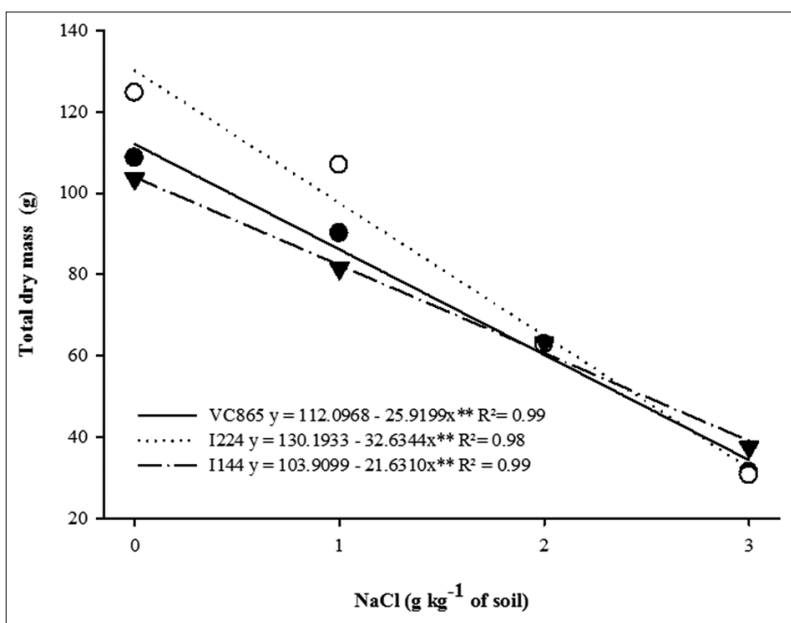

Fig 7. Total dry mass (TDM) at 60 days after transplanting in Eucalyptus clones grown at different soil salinity levels.

The positive correlation between stomatal conductance, transpiration, and photosynthesis that was found among the clones in this study confirms that the plants were under water stress in response to high soil salinity, which led to the partial stomata closure, decreased transpiration and led to sharp decline in photosynthetic rates. Salt stress is usually associated with water stress, since high concentrations of sodium in soil promote the restriction of water absorption by plants (Plazek et al., 2013). Under these conditions, a reduction in stomata opening occurs in order to avoid excessive loss of water from plant leaves, thus restricting their photosynthetic capacity by reduction in $\mathrm{CO}_{2}$ acquisition (Coscolin et al., 2011; Kumar et al., 2014).

The photosynthetic responses of plants to salinity are complex, since these are dependent on the time and salt concentration to which they are subjected (Chaves et al., 2009). As was observed in this study, clone I144 increased its stomatal conductance, transpiration and photosynthesis when exposed to low salinity (1.67 $\mathrm{g} \mathrm{NaCl} \mathrm{kg}^{-1}$ of soil), mainly at $60 \mathrm{DAT}$, whereas the same clone showed superior photosynthetic performance to the other clones, although it was also reduced with increasing soil salinity. This condition probably indicates the possible acclimatization of I144 to salt stress, since there were more pronounced reductions of $g s, E$ and $A$, in the other clones, notably in I224, suggesting that this clone is more sensitive to salt stress.

Bhargava et al. (2014) and Sixto et al. (2016), in working with Eucalyptus under salt stress, observed that the salinity promoted the reduction of gas exchange in plants. In a similar way, studies done with Anacardium occidental (Bezerra et al., 2003), Ricinus communis L. (Pinheiro et al., 2008), and Jatropha curcas L. (Cavalcante et al., 2018) cultivated in saline soil have also confirmed that gas exchanges are negatively affected by salinity, as observed among Eucalyptus clones.
Reductions in gas exchange, caused by salt stress, contributed to reduction in biomass production, which can be confirmed by the correlations of $g s, A$ and $A / C i$ with the TDM, in the largest salt concentrations. Indeed, biomass production is reduced as a consequence of less $\mathrm{CO}_{2}$ assimilation, as has been verified also in Eucalyptus plants (Sixto et al. 2016) and in Jatropha curcas L. (Cavalcante et al. 2018) under salt stress.

Increase in the internal $\mathrm{CO}_{2}$ concentration due to increased salt stress in the Eucalyptus clones is possibly related to the non-stomatal factors such as reduction of rubisco activity and concentration and reduction in the final products of the photochemical phase of photosynthesis, ATP and NADPH (ZIVCAK et al., 2013). In this stress situation, the plant cannot consume saturated $\mathrm{CO}_{2}$ once reduction of the internal $\mathrm{CO}_{2}$ concentration with decreases in stomatal conductance is expected, if the photosynthetic apparatus is not damaged by salinity (Kalaji et al., 2011).

The carboxylation efficiency reduced according to the fall of photosynthesis in Eucalyptus clones under high concentrations of salinity, as verified in the positive correlation between these variables and highlighting clone I224, that presented more reductions of $A / \mathrm{Ci}$ and $A$. The reduction of $A / \mathrm{Ci}$ means the occurrence of metabolic damage, which may be related to decrease in activity of the enzyme Rubisco, involved in the $\mathrm{CO}_{2}$ fixation process, and other enzymes related to photosynthesis (Ashraf and Harris, 2013). However, the clone I144 was more efficient in carboxylation, in other words, that was what lower losses in fixing $\mathrm{CO}_{2}$ by salt stress.

$\mathrm{Fv} / \mathrm{Fm}$ decreased in all clones with increased soil salinity, however, these reductions were expressively small. Stressed plants had Fv/Fm values higher than 0.75, suggesting that the photosynthetic apparatus was not damaged by the salinity of the soil, since the variation of $\mathrm{Fv} / \mathrm{Fm}$ between 0.75 and 0.85 indicates the integrity of the photosynthetic apparatus, with absence of photoinhibitory damage in photosystem II (Bolhàr-Nordenkampf et al., 1989). However, clone I144 stood out with the highest values of $\mathrm{Fv} / \mathrm{Fm}$, which suggests for it to be more tolerant to soil salinity, indicated by the greater integrity of the photosynthetic apparatus in this stress situation.

In a study with barley cultivars under saline conditions, the $\mathrm{Fv} / \mathrm{Fm}$ ratio decreased with increasing salinity, with lower intensity in the more tolerant cultivar (Kalaji et al., 2011), also found in Jatropha curcas in which soil salinity reduced $\mathrm{Fv} / \mathrm{Fm}$, especially in the hottest hours of the day (Cavalcante et al., 2018). In this sense, the maximum photochemical efficiency of PSII is quite efficient as an indicator of disturbances in the photosynthetic apparatus 
caused by soil salinity (Kalaji et al., 2011; Cavalcante et al., 2018), since low values of $\mathrm{Fv} / \mathrm{Fm}$ are considered a stress sensitivity response (Sá et al., 2018).

The Eucalyptus clones presented reduction in the SPAD index and in photosynthetic pigments as a negative effect of soil salinity. However, clone I144 was less affected, because it was able to maintain higher levels of chlorophyll even under salt stress, indicating greater tolerance to this stress condition. On the other hand, clones VC865 and I224 presented decreases of chlorophylls and SPAD index with the increase of $\mathrm{NaCl}$ in the soil. These results can be attributed to the ionic effect of $\mathrm{Na}$, which promotes deficiency of some nutrients essential for the metabolism of chlorophyll (Sá et al., 2015).

Chlorophyll degradation also indicates photochemical disturbances in the light collecting complex and in the PSII reaction centers caused by salinity (Bhargava et al., 2014; Cavalvante et al., 2018), which may have occurred in clones VC865 and I224. The reduction in chlorophyll levels caused by stress becomes one of the main limiting factors of photosynthetic activity by directly reflecting the maximum efficiency of PSII (Santos and Silva, 2015), as observed in Jatropha curcas, in which the salinity of the soil reduced the levels of chlorophyll, as well as reducing photosynthesis and the maximum efficiency of photosystem II (Cavalcante et al., 2018). Therefore, chlorophylls have often been used to identify damages in the photosynthetic system of plants caused by soil salinity, being that its degradation is an indication of blocking or reduction of photochemical activity (Santos and Silva, 2015; Cavalcante et al., 2018).

Clone I144 also showed lower reduction of carotenoid content in relation to VC865 and I224 with the increase of the salinity of the soil, indicating that the higher stability of $\mathrm{Fv} / \mathrm{Fm}$ in that clone may be due to photoprotection promoted by carotenoids, as was observed by the correlation between these variables. It's emphasized that the degradation of these pigments interferes in the photoprotection exerted by the plant, increasing the chances of photo-oxidation under stress conditions (Silva et al., 2014; Santos and Silva, 2015), therefore, plants that maintain carotenoids are more tolerant to stress. Besides that, the reduction of pigments along with PSII disorders, by the reduction of $\mathrm{Fv} / \mathrm{Fm}$, leads to a decrease in TDM, considering the correlations between these variables, especially when the plants were stressed.

\section{CONCLUSIONS}

In conclusion, clone 144 presents mechanisms of soil salinity tolerance, such as reduction of stomatal conductance, transpiration, photosynthesis, photochemical efficiency of PSII, photosynthetic pigment contents and TDM. On the other hand, clone I224 presents greater physiological damage, which indicates greater sensitivity to salt stress, while clone VC865 demonstrates moderate sensitivity. Variables related to photosynthetic performance, such as gas exchanges, photochemical efficiency of PSII and photosynthetic pigments are important as criteria of tolerance to salt stress, and can be used to identify Eucalyptus clones tolerant to this condition.

\section{ACKNOWLEDGEMENT}

This study was supported by the FAPEAL - Foundation for Research Support of the State of Alagoas, Brazil.

\section{Author's contributions}

All authors contributed extensively to the work presented in this article. J.R.A. and S.O.M.J.: designed and performed research, wrote and revised the manuscript. C.M.S., V.M.F. and L.E.: contributed to revise the manuscript. A.F.S.S., V.M.S., L.T.B. and J.R.R.S.: carried out the experiments.

\section{REFERENCES}

Ahmed, I. M., U. A. Nadira, N. Bibi, F. Cao, X. He, G. Zhang and F. Wu. 2015. Secondary metabolism and antioxidants are involved in the tolerance to drought and salinity, separately and combined, in Tibetan wild barley. Environ. Exp. Bot. 111: 1-12.

Albaugh, J. M., P. J. Dye and J. S. King. 2013. Eucalyptus and water use in South Africa. Int. J. Forest Res. Article. 2013: 1-11.

Ashraf, M., and P. J. C. Harris. 2013. Photosynthesis under stressful environments: An overview. Photosynthetica. 51: 163-190.

Bhargava, K. M., A. Singh and A. Kumar. 2014. Seasonal variation in physiology of Eucalyptus genotypes in relation to soil salinity. Int. J. Adv. Res. 2: 281-290.

Bezerra, M. A., R. D. Oliveira, C. D. Lacerda, J. T. Prisco and E. G. Filho. 2003. Fotossíntese de plantas de cajueiro-anão precoce submetidas ao estresse salino. Proc. Interamer. Soc. Trop. Hort. 2003: 47.

Bolhàr-Nordenkampf, H. R., S. P. Long, N. R. Baker, G. Oquist, U. Schreider and E. G. Lechner. 1989. Chlorophyll fluorescence as probe of the photosynthetic competence of leaves in the field: A review of current instrument. Funct. Ecol. 3: 497-514.

Brito, M. E., L. A. Soares, W. S. S. Filho, P. D. Fernandes, E. C. Silva, F. V. Sá and L. A. Silva. 2018. Emergence and morphophysiology of Sunki mandarin and other citrus genotypes seedlings under saline stress. Span. J. Agric. Res. 16(1): 801.

Campos, M. L. D., B. S. D. Hsie, J. A. D. Granja, R. M. Correia, J. S. D. Almeida Cortez and M. F. Pompelli. 2012. Photosynthesis and antioxidant activity in Jatropha curcas L. under salt stress. Braz. J. Plant Physiol. 24: 55-67.

Cavalcante, P. G. S., C. M. Santos, H. C. L. Filho, J. R. L. Avelino, L. Endres. 2018. Morpho-physiological adaptation of Jatropha curcas L. to salinity stress. Aust. J. Crop Sci. 12: 563-571.

Chaves, M. M., J. Flexas and C. Pinheiro. 2009. Photosynthesis 
under drought and salt stress: regulation mechanisms from whole plant to cell. Ann. Bot. 103: 551-560.

Coscolin, R. B. S., F. Broetto, J. A. Marchese, M. C. Campohermoso and M. V. Paladini. 2011. Effects of hydric deficiency on gas exchange parameters and metabolism of Eucalyptus grandis clones. Braz. J. Plant Physiol. 23: 255-262.

Ferreira, D F. 2014. SISVAR: A guide for its bootstrap procedures in multiple comparisons. Ciênc. Agrotec. 38: 109-112.

Flores, T. B., C. A. Alvares, V. C. Souza and J. L. Stape. 2016. Eucalyptus no Brasil: Zoneamento Climático e Guia Para Identificação. IPEF, Brasil.

Goldemberg, J. 2009. Biomassa e energia. Quím. Nova. 32: 582-587.

Guehl, J. and G. Aussenac. 1987. Photosynthesis decrease and stomatal control of gas Exchange in Abies alba Mill. in response to capour pressure difference. Plant Physiol. 83: 316-322.

Harfouche, A., R. Meilan and A. Altman. 2014. Molecular and physiological responses to abiotic stress in forest trees and their relevance to tree improvement. Tree Physiol. 34: 1181-1198.

Hishida, M., F. Ascencio-Valle, H. Fujiyama, A. Orduño-Cruz, T. Endo and J. A. Larrinaga-Mayoral. 2014. Antioxidant enzyme responses to salinity stress of Jatropha curcas and $J$. cinerea at seedling stage. Russ. J. Plant Physiol. 61: 53-62.

Ibá Industria Brasileira de Árvores. 2017. Brasília. Relatório Ibá. 80p. Available from: http://www.iba.org/images/shared/Biblioteca/ IBA_RelatorioAnual2017.pdf. [Last accessed on 2018 Jan 15].

Kalaji, H. M., K. Bosa, J. Koscielniak and K. Zuk-Golaszewska. 2011. Effects of salt stress on photosystem II efficiency and CO2 assimilation of two Syrian barley landraces. Environ. Exp. Bot. 73: 64-72.

Kumar, T., M. R. Khan, S. A. Jan, N. Ahmad, N. N. Ali, M. A. Zia, S. Roomi, A. Iqbal and G. M. Ali. 2014. Efficientregeneration and genetic transformation of sugarcane withAVP1 gene. Am. Eurasian J. Agric. Environ. Sci. 14: 165-171.

Lichtenthaler, H. K. 1987. Chlorophylls and carotenoids: Pigments of photosynthetic biomembranes. Methods Enzymol. 148: 350-382.

Lopes, J. L. W., I. A. Guerrini, M. R. D. Silva, J. C. C. Saad and C. F. Lopes. 2011. Estresse hídrico em plantio de Eucalyptus grandis vs. Eucalyptus urophylla, em função do solo, substrato e manejo hídrico de viveiro. Rev. Árvore. 35: 31-39.

Lopes, V. A., B. R. Souza, D. R. Moura, D. Z. Silva, P. S. Silveira and F. S. Matos. 2015. Initial growth of Eucalyptus plants treated with gibberellin. Afr. J. Agric. Res. 10: 1251-1255.

Maxwell, K. and G. N. Johnson. 2000. Chlorophyll fluorescence: A pratical guide. J. Exp. Bot. 51: 659-668.

Medeiros, D. B., E. C. Silva, R. J. M. Nogueira, M. M. Teixeira and M. S. Buckeridge. 2013. Physiological limitations in two sugarcane varieties under water suppression and after recovering. Theor. Exp. Plant Physiol. 25: 213-222.

Muller, C., B. E. R. Hodecker, A. Merchant, N. F. D. Barros. 2017. Nutritional efficiency of Eucalyptus clones under water stress. Rev. Bras. Ciênc. Solo. 41: e160528.

Munns, R. 2005. Genes and salt tolerance: Bringing them together. New Phytol. 167: 645-663.

Munns, R. and M. Gilliham. 2015. Salinity tolerance of crops what is the cost? New Phytol. 208: 668-673.

Munns, R. and M. Tester. 2008. Mechanism of salinity tolerance. Annu. Rev. Plant Biol. 59: 651-681.

Neves, T. A., T. P. Protásio, P. F. Trugilho, M. L. A. Valle, L. C. Sousa and C. M. M. Vieira. 2013. Qualidade da madeira de clones de Eucalyptus em diferentes idades para a produção de bioenergia. Rev. Bras. Ciênc. Agrár. 56: 139-148.
Novais, R. F., J. C. L. Neves and N. F. Barros. Ensaio em ambiente controlado. In: Oliveira, A. J., W. E. Garrido, J. D. Araújo and S. Lourenço. 1991. (Eds.), Métodos de Pesquisa em Fertilidade do Solo. Brasília, Embrapa-SEA, pp. 189-254.

Pinheiro, H. A., J. V. Silva, L. Endres, V. M. Ferreira, C. A. Câmara, F. F. Cabral, J. F. Oliveira, L. W. T. Carvalho, J. M. Santos and B. G. S. Filho. 2008. Leaf gas exchange, chloroplastic pigments and dry matter accumulation in castor bean (Ricinus communis $\mathrm{L}$ ) seedlings subjected to salt stress conditions. Ind. Crops Prod. 27: 385-392.

Plazek, A., M. Tatrzańska, M. Maciejewski, J. Koscielniak, K. Gondek, J. Bojarczuk and F. Dubert. 2013. Investigation of the salt tolerance of new polish bread and durum wheat cultivars. Acta Physiol. Plant. 35: 2513-2523.

Prisco, J. T. and E. G. Filho. 2010. Fisiologia e bioquímica do estresse salino em plantas. In: Gheyi, H. R., N. S. Dias and C. F. Lacerda, (Eds.), Manejo da Salinidade na Agricultura: Estudos Básicos e Aplicados. INCTSal, Fortaleza, CE, pp. 143-159.

Richards, L. A. 1954. Diagnosis and improvement of saline and alkali soils. In: Agriculture Handbook. Vol. 60. United States Salinity Laboratory, Washington, DC, p. 160.

Sá, F. V. D., H. R. Gheyi, G. S. D. Lima, E. P. D. Paiva, R. C. Moreira and L. D.A. Silva. 2018. Water salinity, nitrogen and phosphorus on photochemical efficiency and growth of West Indian cherry. Rev. Bras. Engenharia Agríc. Ambient. 22(3): 158-163.

Sá, F. V. S., M. E. B. Brito, M. E. B., A. de Silva, R. C. L. Moreira, P. D. Fernandes and L. C. Figueiredo. 2015. Fisiologia da percepção do estresse salino em híbridos de tangerineira sunki Comum sob solução hidropônica salinizada. Comun. Sci. 6: 463-470.

Santos, C. M. and M. A. Silva. 2015. Physiological and biochemical responses of sugarcane to oxidative stress induced by water deficit and paraquat. Acta. Physiol. Plant 37: 1-14.

Santos, C. M., L. Endres, V. M. Ferreira, J. V. Silva, E. V. Rolim and H. C. W. Filho. 2017. Photosynthetic capacity and water use efficiency in Ricinus communis (L.) under drought stress in semi-humid and semi-arid areas. An. Acad. Bras. Ciênc. 89: 3015-3029.

Sengar, K., R. S. Sengar and A. Singh. 2013. Biotechnological and genomic analysis for salinity tolerance in sugarcane. Int. J. Biotech Bioeng. Res. 4: 407-414.

Silva, A. L. L., Y. Oliveira, R. Dibax, J. L. Costa, G. N. Scheidt, M. P. Machado, E. P. Guerra, G. E. Brondani and S. A. O. Alves. 2012. Hydroponics growth of Eucalyptus saligna Sm. on salt-stress mediated by sodium chloride. J. Biotechnol. Biodivers. 3: 213-218.

Silva, M. A., C. M. Santos, H. S. Vitorino and A. F. L. Rhein. 2014. Pigmentos fotossintéticos e índice SPAD como descritores de intensidade do estresse por deficiência hídrica em cana-deaçúcar. Biosci. J. 30: 173-181.

Sixto, H., B. D. González-González, J. J. Molina-Rueda, A. GarridoAranda, M. M. Sanchez, G. López, F. Gallardo, I. Canellas, F. Mounet, J. G. Pettenati and F. Cantón. 2016. Eucalyptus spp. and Populus spp. coping with salinity stress: An approach on growth, physiological and molecular features in the context of short rotation coppice (SRC). Trees. 30: 1873-1891.

Tonello, K. C. and J. T. Filho. 2011. Efeito das variáveis ambientais no comportamento ecofisiológico de dois clones de Eucalyptus grandis x Eucalyptus urophylla: Condições de campo. Sci. For. 39: 419-431.

Vellini, A. L. T., N. F. Paula, P. L. C. Alves, L. C. Pavani, C. A. V. Bonine, E. A. Scarpinati and R. C. Paula. 2008. Respostas fisiológicas de diferentes clones de eucalipto sob diferentes regimes de irrigação. Rev. Árvore. 32: 651-663.

Vieira, G. E. G., A. P. Nunes, L. F. Teixeira and A. G. N. Colen. 2014a. 
Biomassa: Uma visão dos processos de pirólise. Rev. Liberato. 15: 167-177.

Vieira, G. H. S., E. C. Mantovani, G. C. Sediyama and F. T. Delazari. 2014b. Indicadores morfo-fisiológicos do estresse hídrico para a cultura da cana-de-açúcar em função de lâminas de irrigação.
Biosci. J. 30: 65-75.

Zivcak, M., M. Brestic, Z. Balatova, P. Drevenakova, K. Olsovska, H. M. Kalaji, X. Yang and S. I. Allakhverdiev. 2013. Photosynthetic electron transport and specific photoprotective responses in wheat leaves under drought stress. Photosynth. Res. 117: 529-546. 